\title{
Cardiotoxicity and lung toxicity in male rats induced by long-term exposure to iron oxide and silver nanoparticles
}

\author{
MOKHTAR IBRAHIM YOUSEF ${ }^{1}$, ABDELSALAM ABDALLA ABUZREDA $^{1}$ and MAHER ABDEL-NABI KAMEL ${ }^{2}$ \\ ${ }^{1}$ Department of Environmental Studies, Institute of Graduate Studies and Research; \\ ${ }^{2}$ Department of Biochemistry, Medical Research Institute, \\ Alexandria University, Alexandria 21561, Egypt
}

Received July 7, 2018; Accepted June 20, 2019

DOI: $10.3892 /$ etm.2019.8108

\begin{abstract}
Engineered nanoparticles (NPs) have been increasingly used in numerous fields over the last decade. In particular, iron oxide NPs $\left(\mathrm{Fe}_{2} \mathrm{O}_{3} \mathrm{NPs}\right.$ ) and silver NPs (AgNPs) have contributed to the current increase in NP usage. However, the possible side effects of increased NP exposure remain not fully elucidated. The present study aimed to assess the toxic effects of $\mathrm{Fe}_{2} \mathrm{O}_{3} \mathrm{NPs}$ and $\mathrm{AgNPs}$, both individually and in combination, on the heart and lungs of male rats. To evaluate the in vivo NP toxic effects, the experimental animals were orally administered with $\mathrm{Fe}_{2} \mathrm{O}_{3} \mathrm{NPs}(5 \mathrm{mg} / \mathrm{kg}$ ) and/or AgNPs $(50 \mathrm{mg} / \mathrm{kg})$. Animals were treated every day for 79 days. The results demonstrated that at the molecular level, $\mathrm{Fe}_{2} \mathrm{O}_{3} \mathrm{NPs}$ and AgNPs caused marked DNA base oxidation as indicated by the elevated DNA content of 8-hydroxy-2'-deoxyguanosine in the heart and lungs. $\mathrm{Fe}_{2} \mathrm{O}_{3} \mathrm{NPs}$ and/or AgNPs decreased paraoxonase 1 , antioxidant enzymes, total antioxidant capacity, and reduced glutathione in heart and lung. A dose-dependent increase in production of creatine kinase, thiobarbituric acid-reactive substances, nitric oxide end products, tumor necrosis factor- $\alpha$, interleukin- 6 and lipid profiles was detected. Histological changes were also evident in heart
\end{abstract}

Correspondence to: Professor Maher Abdel-Nabi Kamel, Department of Biochemistry, Medical Research Institute, Alexandria University, 165 El-Horreya Street, Alexandria 21561, Egypt

E-mail:maher.kamel@alexu.edu.eg

Abbreviations: 8-OHdG, 8-hydroxy-2'-deoxyguanosine; TBARS, thiobarbituric acid-reactive substances; GSH, reduced glutathione; GST, glutathione S-transferase; SOD, superoxide dismutase; CAT, catalase; ROS, reactive oxygen species; GPX, glutathione peroxidase; LPO, lipid peroxidation; PON1, paraoxinase 1; vLDL, very low-density lipoprotein; ApoB, apolipoprotein B; CK, creatine kinase; HDL-c, high-density lipoprotein-cholesterol; NOx, nitric oxide; LDL, low-density lipoprotein; TL, total lipids; RNS, reactive nitrogen species; TAC, total antioxidant capacity

Key words: iron oxide nanoparticles, silver nanoparticles, 8-hydroxy-2'-deoxyguanosine, cytokines, p53, oxidative stress, cardiotoxicity, lung toxicity and lung tissues. The two NPs demonstrated similar toxic effects for the majority of factors when co-supplemented. In conclusion, the present study identified that $\mathrm{Fe}_{2} \mathrm{O}_{3} \mathrm{NPs}$ and AgNPs, alone and in combination, induced cardiotoxicity and lung toxicity. Furthermore, findings demonstrated that there was a greater toxic effect due to administration of both NPs compared to individual administration. It was hypothesized that the toxic effects may be mediated through the induction of oxidative DNA damage, lipid peroxidation, shifting redox status, disrupted gene expression, and deregulation in cytokine production.

\section{Introduction}

Nanoparticles (NPs) and other nanomaterials have entered virtually all areas of everyday life which has raised concerns over their toxicity and other potential effects on the body. The biological effects of NPs are determined by various factors including particle size, shape and ability to interact with the surrounding tissue (1).

Metal nanoparticles have widespread applications. Of these, iron oxide NPs $\left(\mathrm{Fe}_{2} \mathrm{O}_{3} \mathrm{NPs}\right)$ and silver NPs (AgNPs) are the most prominent. $\mathrm{Fe}_{2} \mathrm{O}_{3} \mathrm{NPs}$ are found in the environment as particulate matter originating from air pollution and volcanic eruptions. $\mathrm{Fe}_{2} \mathrm{O}_{3} \mathrm{NPs}$ particles can also be generated by traffic, industry and power station emissions. In addition, they are purposely chemically synthesised for a wide variety of applications (2). Similarly, AgNPs are widespread in the environment due to various different industries. Specifically, AgNPs are of interest due to their unique properties (e.g. the size and shape affecting its optical, electrical, and magnetic properties), meaning that they have roles in antimicrobial applications, biosensor materials, composite fibers, cryogenic superconducting materials, cosmetic products and electronic components (3). AgNPs have been predominately utilized for the development of medicines, drug delivery systems, and medical device coatings. An increase in AgNP usage has led to greater concentrations of NPs in the atmosphere and general environment. The most concerning element is their ability to infiltrate groundwater and soil, which are the greatest avenues of exposure. Ingested $\mathrm{Fe}_{2} \mathrm{O}_{3} \mathrm{NPs}$ and AgNPs can be translocated into the bloodstream and distributed throughout vital organs such as the heart, liver, kidney, brain 
and lungs (4), raising concerns about their acute and chronic toxic effects.

There is a compelling body of evidence that addresses the toxicological effects of $\mathrm{Fe}_{2} \mathrm{O}_{3} \mathrm{NPs}$ and $\mathrm{AgNPs}$ on animal cells and tissues $(5,6)$. NPs may cause inflammation, cytokine production, cytoskeletal changes, altered vesicular trafficking, oxidative stress, apoptosis and changes in gene expression and cell signalling (1). Toxicity is further heightened by the metallic nature of $\mathrm{Fe}_{2} \mathrm{O}_{3} \mathrm{NPs}$ and $\mathrm{AgNPs}$. It has been reported that silver ions $\left(\mathrm{Ag}^{+}\right)$are released from $\mathrm{AgNPs}$ in aqueous environments (7) and a study also demonstrated that the cytotoxicity of AgNPs was eliminated after $\mathrm{Ag}^{+}$was chelated by a thiol ligand (8). Furthermore, $\mathrm{Fe}_{2} \mathrm{O}_{3} \mathrm{NPs}$ release free iron, which induces reactive oxygen species (ROS) production through the Fenton reaction process.

The toxicities of $\mathrm{Fe}_{2} \mathrm{O}_{3} \mathrm{NPs}$ and AgNPs are well documented; however, the effects of simultaneous co-exposure to both NPs remain uninvestigated, therefore the present study aimed to address this issue. Rats were subchronically exposed to $\mathrm{Fe}_{2} \mathrm{O}_{3} \mathrm{NPs}$ and $\mathrm{AgNPs}$, as well as to a combination of both, for 79 days and the effects on different organs were assessed. The present study focused on the toxic effects with regards to the lungs and heart, as the role of NP exposure in the development of cardiovascular diseases is of particular concern in nanotoxicology. The aims were to determine the cardiotoxicity and lung toxicity of long-term $\mathrm{Fe}_{2} \mathrm{O}_{3} \mathrm{NPs}$ and $\mathrm{AgNPs}$ exposure, alone and in combination, and also to investigate the different mechanisms that may be involved, including oxidative stress, oxidative DNA damage, and dysregulated cytokine production.

\section{Materials and methods}

Tested compounds and doses. $\mathrm{Fe}_{2} \mathrm{O}_{3} \mathrm{NPs}$ (spherical; $50 \mathrm{~nm}$ particle size; $50-245 \mathrm{~m}^{2} / \mathrm{g}$ surface area) and AgNPs (spherical; $50 \mathrm{~nm}$ particle size; $5.0 \mathrm{~m}^{2} / \mathrm{g}$ surface area) were purchased from Sigma-Aldrich (Merck KGaA). $\mathrm{Fe}_{2} \mathrm{O}_{3} \mathrm{NPs}$ and AgNPs were dispersed in distilled water by sonication for $30 \mathrm{sec}$ to form suspensions before use at doses of $5 \mathrm{mg} / \mathrm{ml}$ and $50 \mathrm{mg} / \mathrm{ml}$, respectively. The hydrodynamic size distribution of each NP in suspension was determined by dynamic light scattering using a Zetasizer Nano ZS (Malvern Instruments, Ltd.). Szalay et al (9) and Sharma et al (10) were consulted to determine the appropriate dosage of $\mathrm{Fe}_{2} \mathrm{O}_{3} \mathrm{NPs}(5 \mathrm{mg} / \mathrm{kg} /$ day) and AgNPs (50 mg/kg/day).

In vivo study and experimental groups. Forty adult male Wistar rats weighing 160-170 g at 5-6 months of age were used in the present study. Animals were provided by the Faculty of Medicine of Alexandria University. Rats had free access to tap water and a basal diet, which were provided ad libitum. Following two weeks of acclimation, animals were divided into 4 equal groups $(n=10)$ : Group 1 served as the control, group 2 was administered with $\mathrm{Fe}_{2} \mathrm{O}_{3} \mathrm{NPs}(5 \mathrm{mg} / \mathrm{kg})$ by oral gavage, group 3 was administered with $\operatorname{AgNPs}(50 \mathrm{mg} / \mathrm{kg})$ by oral gavage, and group 4 was administered with a combination of $\mathrm{Fe}_{2} \mathrm{O}_{3} \mathrm{NPs}(5 \mathrm{mg} / \mathrm{kg})$ and $\mathrm{AgNPs}(50 \mathrm{mg} / \mathrm{kg})$ by oral gavage. The rats were dosed with $\mathrm{Fe}_{2} \mathrm{O}_{3} \mathrm{NPs}$ and AgNPs every day for 79 days with this time period selected to cover two reproductive cycles of spermatogonia to study the reproductive toxicity (unpublished data). No signs of stress were observed in rats from any of the experimental groups during the study period.

All experimental procedures, animal handling, sampling, and scarification were performed in accordance with the Guide for the Care and Use of Laboratory Animals, 8th edition (National Research Council 2011) and were approved by the Research Ethical Committee of the Medical Research Institute of Alexandria University. All efforts were made to minimise the rats' suffering during the experimental period.

Blood sample collection and tissue preparation. On day 79 of the experimental period, all animals were sacrificed by cervical dislocation under anaesthesia (ketamine $100 \mathrm{mg} / \mathrm{kg}$ and xylazine $10 \mathrm{mg} / \mathrm{kg}$ intraperitoneally) in accordance with the literature (11). The final body weight was $<200 \mathrm{~g}$. There were no signs of toxicity at the stated doses of anaesthetic agents. Blood samples were collected in test tubes containing heparin as an anticoagulant and placed immediately on ice. The blood samples were centrifuged at $860 \mathrm{xg}$ for $20 \mathrm{~min}$ to separate the plasma. The plasma was kept at $-80^{\circ} \mathrm{C}$ until the experimental parameters were measured and analysed. The hearts and lungs were immediately removed and washed with chilled saline solution $(0.9 \%)$ followed by the removal of the adhering fat and connective tissues. Then each tissue was divided for the following experiments: DNA isolation for 8-hydroxy-2'-deoxyguanosine (8-OHdG) assessment, DNA fragmentation, RNA isolation for gene expression analysis, histological analysis and finally for ELISA.

Tissue homogenization. Heart and lung tissue was minced and homogenised $(10 \%, \mathrm{w} / \mathrm{v})$, separately, in ice-cold sucrose buffer $(0.25 \mathrm{M})$ in a Potter-Elvehjem type homogeniser. The homogenates were then centrifuged at $10,000 \mathrm{x}$ g for $20 \mathrm{~min}$ at $4^{\circ} \mathrm{C}$, to pellet the cell debris. The supernatant was collected and stored at $-80^{\circ} \mathrm{C}$ for analysis.

Index of oxidative DNA damage measured by 8-OHdG assay. A widely accepted sensitive marker of oxidative DNA damage and oxidative stress is $8-\mathrm{OHdG}$. The determination of DNA damage using 8-OHdG began with the isolation of genomic DNA using a DNeasy kit (Qiagen Inc.) following the manufacturer's instructions. The concentration was determined using Nanodrop. DNA was briefly digested then $5 \mu \mathrm{g} / \mu \mathrm{l}$ (total DNA $200 \mu \mathrm{g}$ ) was incubated with 100 units of DNase I (Bio Basic, Inc) in $40 \mu \mathrm{l}$ Tris/hydrochloric acid $10 \mathrm{mM}$ and $10 \mu 1$ of $0.5 \mathrm{M}$ $\mathrm{MgCl}_{2}$ (final concentration of $20 \mathrm{mM}$ ) at $37^{\circ} \mathrm{C}$ for $1 \mathrm{~h}$. The $\mathrm{pH}$ of the reaction mixture was then lowered with the addition of $15 \mu \mathrm{l}$ of $0.5 \mathrm{M}$ sodium acetate ( $\mathrm{pH} 5.1), 10 \mu \mathrm{l}$ of nuclease P1 (Bio Basic, Inc.) and $30 \mu \mathrm{l}$ of $10 \mathrm{mM} \mathrm{ZnSO}_{4}$, and the mixture was incubated for $1 \mathrm{~h}$. After readjusting the $\mathrm{pH}$ with $100 \mu \mathrm{l}$ of $0.4 \mathrm{M}$ Tris/ $\mathrm{HCl}(\mathrm{pH} 7.8)$ and $20 \mu \mathrm{l}$ alkaline phosphatase (Bio Basic, Inc.), the samples were incubated at $37^{\circ} \mathrm{C}$ for $30 \mathrm{~min}$ then boiled for $10 \mathrm{~min}$. The resultant DNA hydrolysate was used for experimentation using the 8-OH-dG ELISA kit (cat. no. ab201734; Abcam) according to the manufacturer's protocol.

p53 and cytokine assessment using ELISA. The homogenates of heart and lung tissues were used for the determination of 
p53 (cat. no. ELR-p53-1; RayBiotech, Inc.), tumor necrosis factor-alpha (TNF- $\alpha$; cat. no. ab100785) and interleukin-6 (IL-6; cat. no. ab100772) by using respective ELISA kits (Abcam) according to the manufacturer instructions.

Lipid peroxidation assay. The process of lipid peroxidation results in the end product of malondialdehyde (MDA), therefore its quantification is generally used as a marker for lipid peroxidation activity. MDA levels were determined using thiobarbituric acid-reactive substances assay (12). In brief, the heart and lung tissues homogenates were heated with thiobarbituric acid at a low $\mathrm{pH}$ to produce a pink chromogen, which was analysed at a wavelength of $532 \mathrm{~nm}$.

Nitric oxide (NOx) end products. The Griess reaction was used to determine the concentration of NOx end products, nitrite and nitrate, in the deproteinised heart and lung supernatants (13). The Griess reaction was supplemented with the reduction of nitrate to nitrite by nicotinamide-adenine dinucleotide phophate-dependent nitrate reductase. In brief, the first step required the diazotisation of sulphanilic acid with nitrite ions followed by the coupling of this product with diamine, resulting in a measurable pink metabolite, which was analysed at a wavelength of $540 \mathrm{~nm}$.

Antioxidant determination. The total antioxidant capacity (TAC) and the activities of superoxide dismutase (SOD), glutathione peroxidase (GPX), glutathione S-transferase (GST) and catalase (CAT) in the tissue homogenates were measured using colorimetric kits (Bio-Diagnostic, Ltd.). Reduced glutathione (GSH) content was assessed after protein precipitation using a metaphosphoric acid reagent. The assay was based on the oxidation of GSH by 5,5'-dithiobis-(2-nitrobenzoic acid) (DTNB) to yield glutathione disulphide (GSSG) and 5-thio-2-nitrobenzoic acid (TNB). The rate of TNB formation was assessed at $412 \mathrm{~nm}$ and was proportional to the GSH amount present in the sample (14). The rate of formation of TNB was monitored by recording the change in the absorbance at $412 \mathrm{~nm}$. The total GSH content in the samples was determined from a GSH standard curve. The results were subsequently expressed as nmol/g tissue by dividing the concentration of GSH in the sample by the total weight $(\mathrm{g})$ of tissue used to prepare the sample.

Determination of paraoxonase (PON1) and creatine kinase-muscle/brain (CK-MB) activities in the heart. The PON1 enzyme activity in the heart was measured by applying the method of Mueller et al (15). The CK-MB was assayed using an ELISA kit (cat. no. K777; BioVision, Inc.).

Lipid profile assessment. Stored plasma samples were analysed for total lipids (cat. no. 8.05.36.0.0250; Atlas Medical UK), cholesterol (cat. no. 11805), triacylglycerol (TAG; cat. no. 11828) and high-density lipoprotein cholesterol (HDL-c; cat. no. 11557) using commercial kits (BioSystems S.A.). Very low-density lipoprotein-cholesterol (vLDL-c) was calculated by dividing the values of TAG by a factor of 5. Low-density lipoprotein-cholesterol (LDL-c) was determined by the following calculation: LDL-c=cholesterol-(HDL-c + vLDL-c). Rat Apolipoprotein B (ApoB) ELISA kit (cat. no. KT-7394; Kamiya Biomedical
Company) was used for assessment of plasma level of ApoB. All assays were carried out in accordance with manufacturers' instructions.

Histological analysis of heart and lung. Heart and lung specimens were obtained from rats, and immediately fixed in $10 \%$ formalin for $18 \mathrm{~h}$ at room temperature before being treated with a conventional grade of alcohol and xylol, embedded in paraffin and sectioned at 4-6 mm thickness. The sections were stained with haematoxylin and eosin (H\&E) in order to study the histopathological changes using a light microscope at a magnification of $x 400$ as previously described (16).

Statistical analysis. Results are expressed as mean \pm standard error. All statistical analysis was carried out using the general linear model (SAS Institute, Inc.). Multiple comparisons were performed using one-way analysis of variance followed by Duncan's new multiple range test. To test for interactions between the individual treatments when given in combination, a factorial design test was used. $\mathrm{P}<0.05$ was considered to indicate statistical significance.

\section{Results}

Levels of 8-OHdG increase in cardiac and lung tissue following exposure to NPs. A sensitive marker of oxidative DNA damage is $8-\mathrm{OHdG}$. Rats exposed to $\mathrm{Fe}_{2} \mathrm{O}_{3} \mathrm{NPs}$ and AgNPs alone or in combination displayed significantly higher levels of $8-\mathrm{OHdG}$ in their cardiac and lung tissue compared with rats in the control group (Fig. 1). The rats exposed to $\mathrm{Fe}_{2} \mathrm{O}_{3} \mathrm{NPs}$ had higher cardiac and lung 8-OHdG contents compared with rats exposed to AgNPs (Fig. 1). The rats coexposed to both NPs exhibited markedly higher $8-\mathrm{OHdG}$ contents in both cardiac (Fig. 1A) and lung (Fig. 1B) tissues compared with other groups.

Levels of p53, TNF- $\alpha$, and IL-6 increase in cardiac and lung tissue following exposure to NPs. p53 controls the cell cycle to suppress the production of tumours, and acts as genome guard and as an inducer of apoptosis. TNF- $\alpha$ and IL- 6 have important roles in tissue injury and oxidative stress. The results indicated that p53, TNF- $\alpha$ and IL- 6 levels were significantly higher in heart and lung tissues of rats exposed to $\mathrm{Fe}_{2} \mathrm{O}_{3} \mathrm{NPs}$ and AgNPs (Fig. 2). Exposure to AgNPs caused the production of a significantly higher level of p53 in cardiac and lung tissues (Fig. 2A and B), and TNF- $\alpha$ in cardiac tissues (Fig. 2C) compared to the rats exposed to $\mathrm{Fe}_{2} \mathrm{O}_{3} \mathrm{NPs}$. The amount of TNF- $\alpha$ present in lung tissues was lower in the rats exposed to AgNPs compared to the rats exposed to $\mathrm{Fe}_{2} \mathrm{O}_{3} \mathrm{NPs}$. Regarding IL-6 levels (Fig. 2E and F), there was no significant difference in the tissues of rats exposed to $\mathrm{Fe}_{2} \mathrm{O}_{3} \mathrm{NPs}$ and $\mathrm{AgNPs}$. The rats coexposed to both NPs demonstrated significantly higher p53, TNF- $\alpha$, and IL-6 levels compared with the control rats or rats exposed to individual NPs (Fig. 2).

Lipid peroxidation and nitric oxide end products increase following exposure to NPs. NOx is a pleotropic molecule that serves an important role in cell signalling; however, at high concentrations it can act as a pro-oxidant leading 

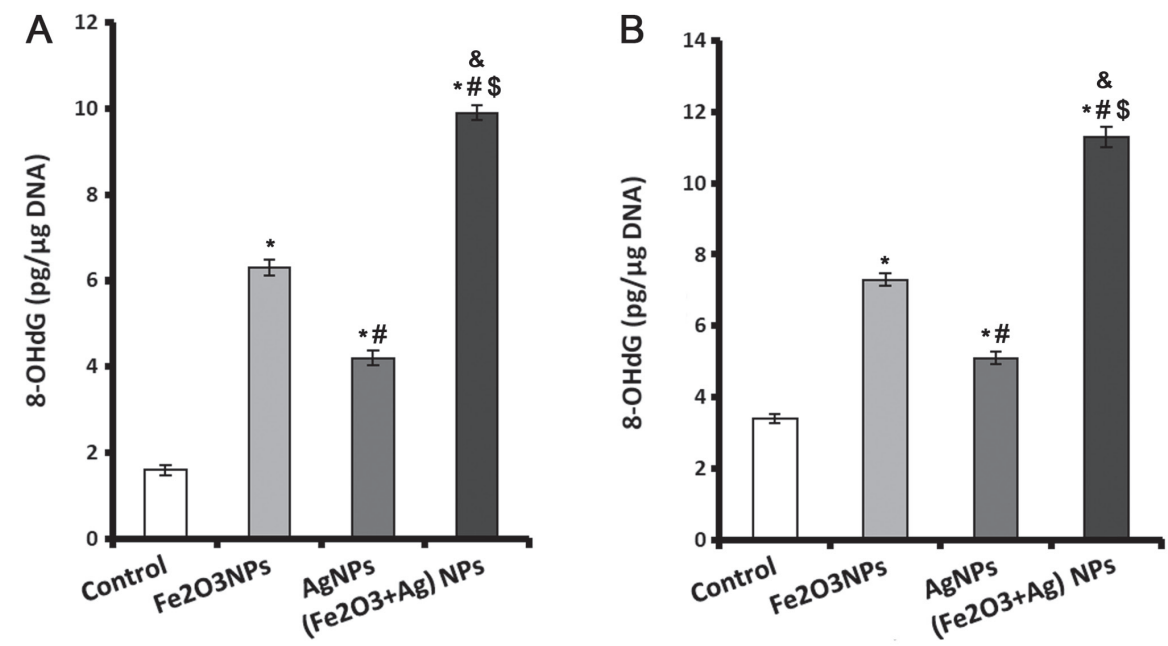

Figure 1. Content of 8-OHdG in control, $\mathrm{Fe}_{2} \mathrm{O}_{3} \mathrm{NP}$-exposed group, AgNP-exposed group, and $\mathrm{Fe}_{2} \mathrm{O}_{3} \mathrm{NP}$ and AgNP-coexposed group. (A) Cardiac and (B) lung tissue 8-OHdG levels measured using ELISA. " $\mathrm{P}<0.05$ vs. control group; ${ }^{\#} \mathrm{P}<0.05$ vs. $\mathrm{Fe}_{2} \mathrm{O}_{3} \mathrm{NP}$-exposed group; ${ }^{\mathrm{P}} \mathrm{P}<0.05$ vs. AgNP-exposed group; ${ }^{\circledR} \mathrm{P}<0.05$ synergistic interactions when both NPs are combined using Factorial Design. 8-OHdG, 8-hydroxy-2'-deoxyguanosine; $\mathrm{Fe}_{2} \mathrm{O}_{3} \mathrm{NP}$, iron oxide nanoparticle; AgNP, silver nanoparticle.
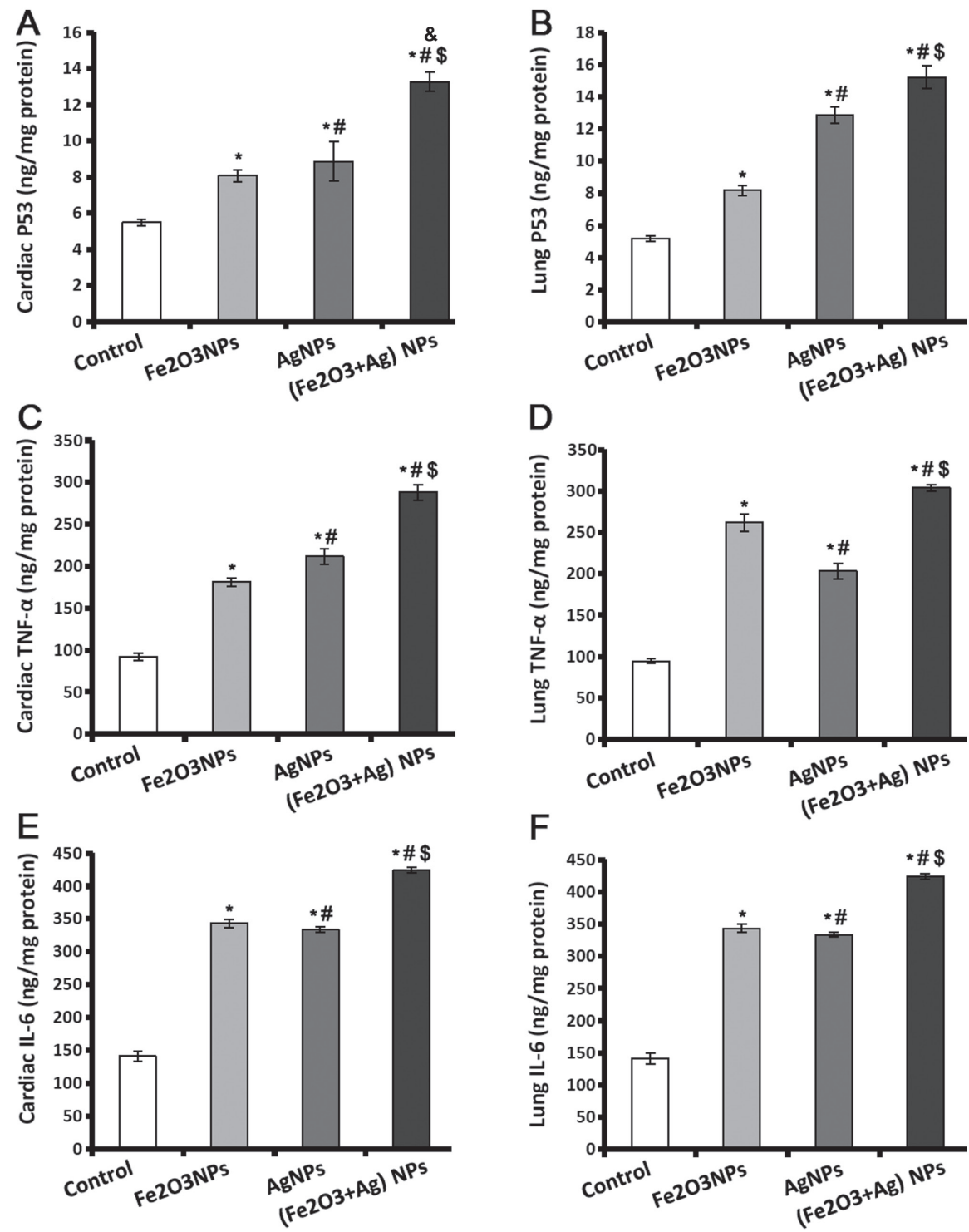

Figure 2. Levels of inflammatory cytokines in control, $\mathrm{Fe}_{2} \mathrm{O}_{3} \mathrm{NP}$-exposed group, AgNP-exposed group, and $\mathrm{Fe}_{2} \mathrm{O}_{3} \mathrm{NP}$ and AgNP-coexposed group. (A) Levels of 553 in rat cardiac and (B) lung tissues. (C) TNF- $\alpha$ levels in rat cardiac and (D) lung tissues. (E) Levels of IL-6 in rat cardiac and (F) lung tissues. ${ }^{*} \mathrm{P}<0.05$ vs. control group; ${ }^{\mathrm{P}}<0.05$ vs. $\mathrm{Fe}_{2} \mathrm{O}_{3} \mathrm{NP}$-exposed group; ${ }^{\mathrm{P}} \mathrm{P}<0.05$ vs. AgNP-exposed group; ${ }^{\&} \mathrm{P}<0.05$ synergistic interactions when both $\mathrm{NPs}$ are combined using Factorial Design. $\mathrm{Fe}_{2} \mathrm{O}_{3} \mathrm{NP}$, iron oxide nanoparticle; AgNP, silver nanoparticle; TNF- $\alpha$, tumor necrosis factor- $\alpha$; IL, interleukin. 
Table I. Heart and lung tissues levels of TBARS, NOx, GSH, SOD, CAT, GST, GPx and TAC of male rats exposed to Fe $\mathrm{O}_{3} \mathrm{NPs}$ and AgNPs.

A, Heart tissues

Experimental groups

\begin{tabular}{lcccc}
\cline { 2 - 5 } Parameter & Control & $\mathrm{Fe}_{2} \mathrm{O}_{3} \mathrm{NPs}$ & $\mathrm{AgNPs}$ & $\mathrm{Fe}_{2} \mathrm{O}_{3} \mathrm{NPs}+\mathrm{AgNPs}$ \\
\hline TBARS (nmol/g tissue) & $59.9 \pm 1.2$ & $78.8 \pm 1.4^{\mathrm{a}}$ & $87.5 \pm 3.4^{\mathrm{a}, \mathrm{b}}$ & $116.4 \pm 3.6^{\mathrm{a}-\mathrm{d}}$ \\
NO $(\mu$ mol/g tissue) & $28.24 \pm 0.74$ & $33.35 \pm 0.30^{\mathrm{a}}$ & $40.78 \pm 2.5^{\mathrm{a}, \mathrm{b}}$ & $47.80 \pm 0.27^{\mathrm{a}-\mathrm{c}, \mathrm{e}}$ \\
GSH (nmol/g tissue) & $5.0 \pm 0.20$ & $3.7 \pm 0.27^{\mathrm{a}}$ & $4.0 \pm 0.06^{\mathrm{a}}$ & $3.3 \pm 0.14^{\mathrm{a}, \mathrm{c}}$ \\
SOD (mU/mg protein) & $38.3 \pm 2.2$ & $24.3 \pm 1.6^{\mathrm{a}}$ & $25.4 \pm 1.7^{\mathrm{a}}$ & $16.2 \pm 0.8^{\mathrm{a}, \mathrm{b}, \mathrm{c}, \mathrm{c}}$ \\
CAT (U/mg protein) & $55.0 \pm 2.94$ & $40.0 \pm 1.11^{\mathrm{a}}$ & $38.0 \pm 1.88^{\mathrm{a}}$ & $18.0 \pm 0.89^{\mathrm{a}-\mathrm{d}}$ \\
GST (U/mg protein) & $0.46 \pm 0.03$ & $0.36 \pm 0.01^{\mathrm{a}}$ & $0.32 \pm 0.02^{\mathrm{a}}$ & $0.29 \pm 0.01^{\mathrm{a}, \mathrm{b}}$ \\
GPX (mU/mg protein) & $26.6 \pm 1.81$ & $18.4 \pm 1.18^{\mathrm{a}}$ & $17.1 \pm 1.29^{\mathrm{a}}$ & $13.4 \pm 0.63^{\mathrm{a}-\mathrm{c}, \mathrm{e}}$ \\
TAC ( $\mu$ mol/g tissue) & $21.50 \pm 0.10$ & $17.27 \pm 0.31^{\mathrm{a}}$ & $17.08 \pm 0.16^{\mathrm{a}}$ & $14.14 \pm 0.12^{\mathrm{a}-\mathrm{d}}$ \\
\hline
\end{tabular}

B, Lung tissues

\begin{tabular}{|c|c|c|c|c|}
\hline \multirow[b]{2}{*}{ Parameter } & \multicolumn{4}{|c|}{ Experimental groups } \\
\hline & Control & $\mathrm{Fe}_{2} \mathrm{O}_{3} \mathrm{NPs}$ & AgNPs & $\mathrm{Fe}_{2} \mathrm{O}_{3} \mathrm{NPs}+\mathrm{AgNPs}$ \\
\hline TBARS (nmol/g tissue) & $41.0 \pm 1.5$ & $75.2 \pm 2.1^{\mathrm{a}}$ & $70.6 \pm 0.9^{\mathrm{a}}$ & $89.5 \pm 2.7^{\mathrm{a}-\mathrm{c}, \mathrm{e}}$ \\
\hline NO $(\mu \mathrm{mol} / \mathrm{g}$ tissue $)$ & $36.6 \pm 1.73$ & $51.8 \pm 0.81^{\mathrm{a}}$ & $69.7 \pm 0.73^{a, b}$ & $75.6 \pm 0.57^{\mathrm{a}-\mathrm{c}}$ \\
\hline GSH (nmol/g tissue) & $5.7 \pm 0.13$ & $4.7 \pm 0.21^{\mathrm{a}}$ & $4.4 \pm 0.24^{\mathrm{a}}$ & $3.5 \pm 0.18^{\mathrm{a}-\mathrm{c}}$ \\
\hline SOD (mU/mg protein) & $9.0 \pm 0.2$ & $6.7 \pm 0.2^{\mathrm{a}}$ & $7.2 \pm 0.1^{\mathrm{a}}$ & $4.4 \pm 0.2^{\mathrm{a}-\mathrm{d}}$ \\
\hline CAT (U/mg protein) & $42.9 \pm 0.85$ & $28.5 \pm 1.16^{\mathrm{a}}$ & $27.1 \pm 1.66^{\mathrm{a}}$ & $15.5 \pm 0.87^{\mathrm{a}-\mathrm{d}}$ \\
\hline GST (U/mg protein) & $0.57 \pm 0.02$ & $0.44 \pm 0.01^{\mathrm{a}}$ & $0.41 \pm 0.01^{\mathrm{a}}$ & $0.35 \pm 0.02^{\mathrm{a}-\mathrm{c}}$ \\
\hline GPX (mU/mg protein) & $33.8 \pm 0.844$ & $25.1 \pm 0.976^{\mathrm{a}}$ & $26.1 \pm 0.901^{\mathrm{a}}$ & $18.6 \pm 0.879^{\mathrm{a}-\mathrm{d}}$ \\
\hline TAC ( $\mu \mathrm{mol} / \mathrm{g}$ tissue $)$ & $22.8 \pm 0.02$ & $21.1 \pm 0.13^{\mathrm{a}}$ & $18.7 \pm 0.07^{\mathrm{a}, \mathrm{b}}$ & $16.3 \pm 0.07^{\mathrm{a}-\mathrm{c}}$ \\
\hline
\end{tabular}

${ }^{\mathrm{a}} \mathrm{P}<0.05$ vs. control group; ${ }^{\mathrm{b}}<0.05$ vs. $\mathrm{Fe}_{2} \mathrm{O}_{3} \mathrm{NP}$-exposed group; ${ }^{\mathrm{c}} \mathrm{P}<0.05$ vs. AgNP-exposed group; ${ }^{\mathrm{d}} \mathrm{P}<0.05$ synergistic interactions when both NPs are combined using Factorial Design; ${ }^{\mathrm{P}}<0.05$ additive interactions when both NPs are combined using Factorial Design. TBARS, thiobarbituric acid-reactive substances; NOx, nitric oxide end products; GSH, glutathione; SOD, superoxide dismutase; CAT, catalase; GST, glutathione S-transferase; GPx, glutathione peroxidase; TAC, total antioxidant capacity; $\mathrm{Fe}_{2} \mathrm{O}_{3} \mathrm{NPs}$, iron oxide nanoparticles; AgNPs, silver nanoparticles.

to catastrophic cell damage. It has a short half-life, so upon analysis, it is typically identified as total nitrite and nitrate as these are both NOx end products. The male rats exposed to $\mathrm{Fe}_{2} \mathrm{O}_{3} \mathrm{NPs}$ and AgNPs demonstrated significantly higher tissues levels of thiobarbituric acid-reactive substances (TBARS) and NOx compared with the control rats (Table I). The rats exposed to AgNPs demonstrated significantly higher values of both TBARS and NOx in lung tissue and NOx in heart tissue compared with the rats exposed to $\mathrm{Fe}_{2} \mathrm{O}_{3} \mathrm{NPs}$. The rats coexposed to both NPs exhibited a significant elevation in TBARS and NOx content in cardiac and lung tissues compared with all other groups (Table I).

Antioxidant levels decrease following exposure to NPs. The antioxidant parameters detected in the present study included GSH, which represents $90 \%$ of the reducing power of the cell, and antioxidant enzymes SOD, CAT, GPX, and GST, and TAC. Exposure to $\mathrm{Fe}_{2} \mathrm{O}_{3} \mathrm{NPs}$ or AgNPs caused a significant decline in the heart and lung antioxidant parameters compared with the levels found in control rats. (Table I) When comparing rats exposed to $\mathrm{Fe}_{2} \mathrm{O}_{3} \mathrm{NPs}$ and the group exposed to AgNPs the only significant difference was a significantly lower level of TAC in the lung tissues of rats exposed to AgNPs. Of note, rats coexposed to both NPs had significantly lower levels of all antioxidant parameters compared with control rats and also rats exposed to single NPs only (Table I).

PON1 and creatine kinase-MB (CK-MB) levels in cardiac and lung tissue decrease following exposure to NPs. PON1 enzyme is a major antiatherosclerotic component of HDL and has an important role in reducing atherosclerosis. PON1 levels in plasma and heart tissues were significantly lower in rats exposed to $\mathrm{Fe}_{2} \mathrm{O}_{3} \mathrm{NPs}$ or AgNPs compared with control rats (Fig. 3A and B). However, there was no significant difference in PON1 levels between the rats exposed to $\mathrm{Fe}_{2} \mathrm{O}_{3} \mathrm{NPs}$ or AgNPs. Coexposure to both NPs caused a significant decline in the plasma and cardiac levels of PON1 compared with the control group and rats exposed to single NPs only (Fig. 3A and B). 
Table II. Plasma total lipid, triglyceride, cholesterol, LDL-c, vLDL-c, HDL-C, and ApoB of male rats exposed to $\mathrm{Fe}_{2} \mathrm{O}_{3} \mathrm{NPs}$ and AgNPs.

Experimental groups

\begin{tabular}{lcccr}
\cline { 2 - 4 } Parameter $(\mathrm{mg} / \mathrm{dl})$ & $\mathrm{Control}$ & $\mathrm{Fe}_{2} \mathrm{O}_{3} \mathrm{NPs}$ & $\mathrm{AgNPs}$ & $\mathrm{Fe}_{2} \mathrm{O}_{3} \mathrm{NPs}+\mathrm{AgNPs}$ \\
\hline Total lipid & $505 \pm 9.0$ & $610 \pm 14.8^{\mathrm{a}}$ & $654 \pm 18.9^{\mathrm{a}, \mathrm{b}}$ & $706 \pm 21.0^{\mathrm{a}-\mathrm{d}}$ \\
Triglycerides & $112.9 \pm 2.49$ & $130.5 \pm 1.06^{\mathrm{a}}$ & $134.8 \pm 1.17^{\mathrm{a}}$ & $155.1 \pm 2.38^{\mathrm{a}-\mathrm{c}, \mathrm{e}}$ \\
Cholesterol & $141.6 \pm 5.38$ & $169.1 \pm 3.29^{\mathrm{a}}$ & $182.6 \pm 3.10^{\mathrm{a}}$ & $221.6 \pm 5.10^{\mathrm{a}-\mathrm{d}}$ \\
LDL-c & $50 \pm 6.9$ & $88 \pm 6.9^{\mathrm{a}}$ & $107 \pm 4.3^{\mathrm{a}, \mathrm{b}}$ & $157 \pm 7.1^{\mathrm{a}-\mathrm{c}, \mathrm{e}}$ \\
VLDL-c & $23 \pm 0.5$ & $26 \pm 0.5^{\mathrm{a}}$ & $27 \pm 0.2^{\mathrm{a}}$ & $31 \pm 0.5^{\mathrm{a}-\mathrm{c}}$ \\
HDL-c & $69 \pm 1.8$ & $55 \pm 1.8^{\mathrm{a}}$ & $48 \pm 1.9^{\mathrm{a}}$ & $33 \pm 2.0^{\mathrm{a}-\mathrm{d}}$ \\
ApoB & $51 \pm 4.5$ & $79 \pm 4.5^{\mathrm{a}}$ & $91 \pm 2.8^{\mathrm{a}, \mathrm{b}}$ & $127 \pm 4.6^{\mathrm{a}-\mathrm{d}}$
\end{tabular}

${ }^{a} \mathrm{P}<0.05$ vs. control group; ${ }^{\mathrm{b}} \mathrm{P}<0.05$ vs. $\mathrm{Fe}_{2} \mathrm{O}_{3} \mathrm{NP}$-exposed group; ${ }^{\mathrm{C}}<0.05$ vs. AgNP-exposed group; ${ }^{\mathrm{d}} \mathrm{P}<0.05$ synergistic interactions when both NPs are combined using Factorial Design; ${ }^{\mathrm{e}} \mathrm{P}<0.05$ additive interactions when both NPs are combined using Factorial Design. LDL-c, low density lipoprotein-cholesterol; vLDL-c, very low-density lipoprotein-cholesterol; HDL-C, high density lipoprotein-cholesterol; ApoB, Apolipoprotein $\mathrm{B} ; \mathrm{Fe}_{2} \mathrm{O}_{3} \mathrm{NPs}$, iron oxide nanoparticles; AgNPs, silver nanoparticles.
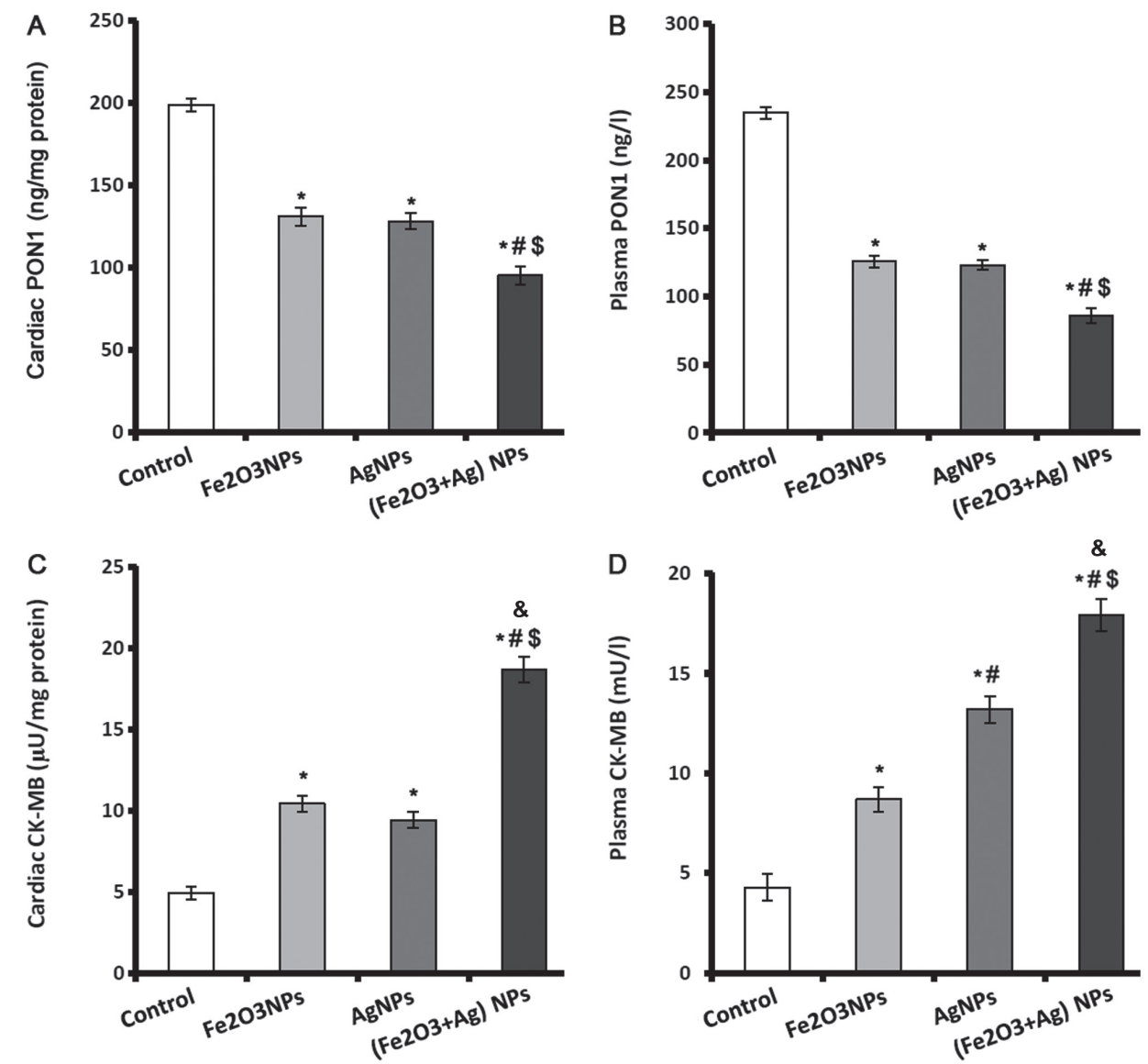

Figure 3. PON1 and CK-MB levels in control, $\mathrm{Fe}_{2} \mathrm{O}_{3}$ NP-exposed group, AgNP-exposed group, and $\mathrm{Fe}_{2} \mathrm{O}_{3} \mathrm{NPs}$ and AgNP-coexposed group. (A) Levels of PON1 in cardiac tissue and (B) in plasma. (C) Activity of CK-MB in cardiac tissues and (D) in plasma. ${ }^{*} \mathrm{P}<0.05$ vs. control group; ${ }^{*} \mathrm{P}<0.05$ vs. $\mathrm{Fe}_{2} \mathrm{O}_{3} \mathrm{NPs}$ exposed group; ${ }^{\$} \mathrm{P}<0.05$ vs. AgNPs exposed group; ${ }^{\circledR} \mathrm{P}<0.05$ synergistic interactions when both NPs are combined using Factorial Design. PON1, paraoxonase; CK-MB, creatine kinase-muscle/brain; $\mathrm{Fe}_{2} \mathrm{O}_{3} \mathrm{NP}$, iron oxide nanoparticle; AgNP, silver nanoparticle.

CK-MB is an important cardiac marker used to assist diagnoses of myocardial infarction. The activity of CK-MB was significantly elevated in the cardiac tissues and plasma of rats exposed to $\mathrm{Fe}_{2} \mathrm{O}_{3} \mathrm{NPs}$ or AgNPs (Fig. 3C and D).
AgNPs exposure caused significantly higher plasma activity of CK-MB than exposure to $\mathrm{Fe}_{2} \mathrm{O}_{3} \mathrm{NPs}$. Coexposure to both NPs significantly elevated the activity of CK-MB in plasma and cardiac tissues by $>3$-fold (Fig. 3C and D). 
Table III. Semi-quantitative analysis of heart and lung histology of male rats exposed to $\mathrm{Fe}_{2} \mathrm{O}_{3} \mathrm{NPs}$ and $\mathrm{AgNPs}$.

A, Heart tissue

Experimental groups

\begin{tabular}{lcccc}
\cline { 2 - 4 } Parameter $(\mathrm{mg} / \mathrm{dl})$ & $\mathrm{Control}$ & $\mathrm{Fe}_{2} \mathrm{O}_{3} \mathrm{NPs}$ & $\mathrm{AgNPs}$ & $\mathrm{Fe}_{2} \mathrm{O}_{3} \mathrm{NPs}+\mathrm{AgNPs}$ \\
\hline Loss of cross striation & - & ++ & + & ++ \\
Fragmentation of sarcoplasm & - & ++ & + & +++ \\
Cytoplasmic vacuolization in cardiac muscles & - & ++ & + & ++ \\
Degenerative changes in myocardial fibers & - & ++ & ++ & +++ \\
\hline
\end{tabular}

B, Lung tissue

Experimental groups

\begin{tabular}{|c|c|c|c|c|}
\hline Parameter (mg/dl) & Control & $\mathrm{Fe}_{2} \mathrm{O}_{3} \mathrm{NPs}$ & AgNPs & $\mathrm{Fe}_{2} \mathrm{O}_{3} \mathrm{NPs}+\mathrm{AgNPs}$ \\
\hline $\begin{array}{l}\text { Extravasations of red blood } \\
\text { cells into long parenchyma }\end{array}$ & - & ++ & +++ & ++++ \\
\hline Interstitial inflammation & - & ++ & ++ & ++++ \\
\hline Alveolar wall thickening & - & ++ & +++ & ++++ \\
\hline Collapse of terminal bronchioles & - & ++ & +++ & ++++ \\
\hline Fibrosis & - & + & ++ & +++ \\
\hline Alveolar macrophages & - & ++ & +++ & ++++ \\
\hline Polymorphs infiltration & - & ++ & +++ & ++++ \\
\hline
\end{tabular}

-, No change; +, mild change; ++, moderate change; +++, moderate to marked change; and ++++, marked change. $\mathrm{Fe}_{2} \mathrm{O}_{3} \mathrm{NPs}$, iron oxide nanoparticles; AgNPs, silver nanoparticles.

Lipid profile parameters. The plasma levels of total lipid, triglycerides, cholesterol, LDL-c, vLDL-c and ApoB of rats exposed to $\mathrm{Fe}_{2} \mathrm{O}_{3} \mathrm{NPs}$ or AgNPs were significantly higher compared with control rats. The total lipids, LDL-c and ApoB were significantly higher in the rats exposed to AgNPs compared with those exposed to $\mathrm{Fe}_{2} \mathrm{O}_{3} \mathrm{NPs}$, whilst the other lipid profile parameters demonstrated no significant difference between the two groups (Table II). There were significantly lower levels of HDL-c in the rats exposed to either $\mathrm{Fe}_{2} \mathrm{O}_{3} \mathrm{NPs}$ or AgNPs compared with the control group. The rats coexposed to both NPs displayed significantly higher levels of all lipid profile parameters, with the exception of HDL-c which displayed significantly lower levels, compared with the control rats and rats exposed to single NPs only (Table II).

Histological changes in rat lung and heart following exposure to NPS. The hearts of rats in the control group had normal myofiber cells with unaffected architectures (Fig. 4A), whilst rats exposed to $\mathrm{Fe}_{2} \mathrm{O}_{3} \mathrm{NPs}$ demonstrated effects of myocardial degeneration (Fig. 4B). Similarly, analysis of the rat heart tissue exposed to AgNPs (Fig. 4C) revealed fragmentation of sarcoplasm and degeneration changes in myocardial fibers. The heart tissues of the coexposed rats revealed loss of cross striation and also myocardial degeneration changes (Fig. 4D).

The lung tissue of control rats demonstrated normal alveoli and bronchi lined mucous secreting columnar respiratory epithelium (Fig. 5A). However, the lung tissues belonging to rats exposed to $\mathrm{Fe}_{2} \mathrm{O}_{3} \mathrm{NPs}$ (Fig. 5B) demonstrated a moderate influx of polymorph, lymphocytes, and macrophages into perivascular tissue. Similarly, the lung tissues of rats administered with AgNPs (Fig. 5C) displayed an influx of polymorph, lymphocytes, and macrophages into the surrounding lung alveoli and perivascular cuff. The lung tissue from coexposed rats (Fig. 5D) demonstrate a moderate influx of polymorph, lymphocytes, and histiocytes into the surrounding perivascular tissue and surrounding bronchi. Semi-quantitative analysis was carried out on the heart and lung histology images of the different rat groups (Table III).

\section{Discussion}

Widespread medical and industrial NP applications increase the risk of human exposure to various NPs that may cause synergistic toxicities on internal organs. The cardiovascular and respiratory systems are of particular concern as they face the most interaction with NPs in medical processes and through general environmental exposure. The present study confirmed the cardiotoxicity and lung toxicity of both $\mathrm{Fe}_{2} \mathrm{O}_{3} \mathrm{NPs}$ and AgNPs, and also demonstrated their synergistic and additive effects in inducing these toxicities.

Damage to DNA is a fundamental example of cellular toxicity, and it is critical to identify damage caused by NPs 



Figure 4. Histological analysis of haematoxylin and eosin stained rat heart tissues of control, $\mathrm{Fe}_{2} \mathrm{O}_{3} \mathrm{NP}$-exposed group, $\mathrm{AgNP}$-exposed group, and $\mathrm{Fe} \mathrm{O}_{3} \mathrm{NP}$ and AgNP-coexposed group. (A) Control rats demonstrated normal myofiber cells and normal architecture. (B) Heart tissues of $\mathrm{Fe}_{2} \mathrm{O}_{3} \mathrm{NP}$-exposed group revealed myocardial degeneration changes. (C) Heart of AgNP-exposed group revealed fragmentation of sacroplasm and degeneration changes in myocardial fibers. (D) Heart of the $\mathrm{Fe}_{2} \mathrm{O}_{3} \mathrm{NP}$ and $\mathrm{AgNP}$-coexposed group revealed loss of cross striation and severe myocardial degeneration changes (magnification, $\mathrm{x} 400$ ). $\mathrm{Fe}_{2} \mathrm{O}_{3} \mathrm{NP}$, iron oxide nanoparticle; AgNP, silver nanoparticle.

A

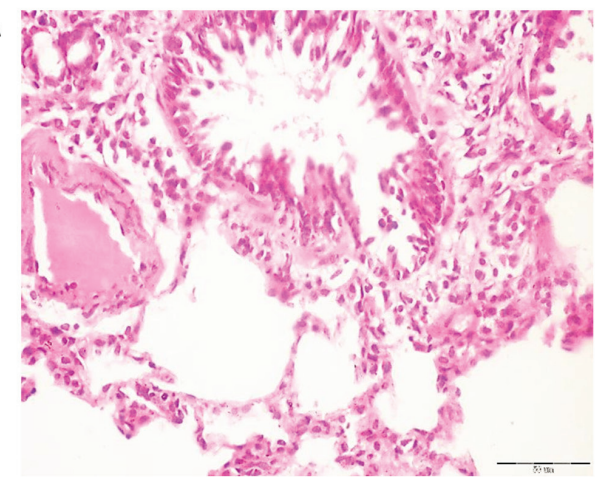

(3)

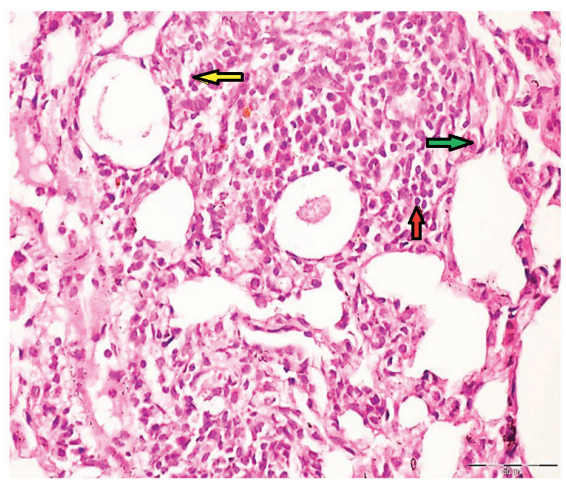

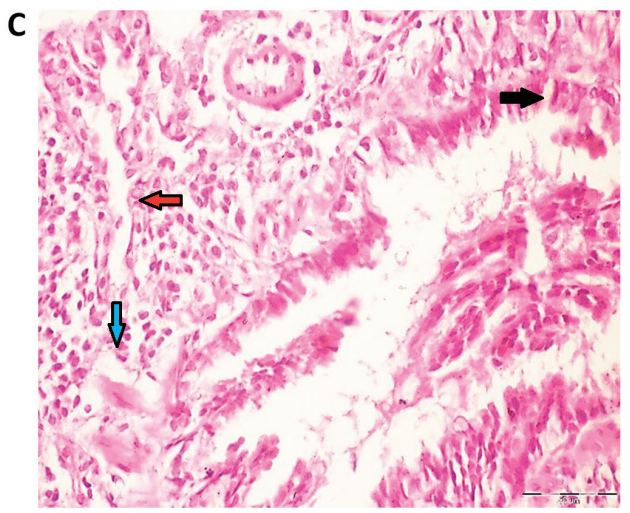

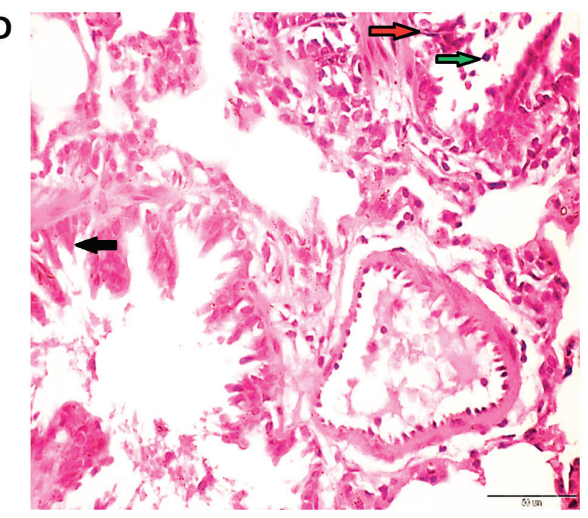

Figure 5. Histological analysis of haematoxylin and eosin stained rat lung tissues of control, $\mathrm{Fe}_{2} \mathrm{O}_{3} \mathrm{NP}$-exposed group, $\mathrm{AgNP}$-exposed group, and $\mathrm{Fe} \mathrm{O}_{3} \mathrm{NP}$ and AgNP-coexposed group. (A) Lung of control rats revealed normal alveoli, bronchi lined mucous secreting columnar respiratory epithelium. (B) Lung of $\mathrm{Fe}_{2} \mathrm{O}_{3} \mathrm{NP}$-exposed group demonstrated a moderate influx of polymorphs (green arrow), lymphocytes (red arrow) and macrophages (yellow arrow) into the perivascular tissue. (C) Lung of AgNP-exposed group demonstrated an influx of lymphocytes (red arrow) and histocytes (blue arrow) into the surrounding lung alveoli and perivascular cuff. (D) Lung of the $\mathrm{Fe}_{2} \mathrm{O}_{3} \mathrm{NP}$ and AgNP-co-exposed group demonstrated a moderate influx of polymorphs (green arrow), and lymphocytes (green arrow) into the surrounding perivascular tissue and bronchi (black arrow; magnification, $\mathrm{x} 400$ ). $\mathrm{Fe}_{2} \mathrm{O}_{3} \mathrm{NP}$, iron oxide nanoparticle; AgNP, silver nanoparticle. 
as DNA damage is highly correlated with an increased risk of cancer. In the present study, 8-OHdG was employed as a sensitive indicator for oxidative DNA damage. Analysis demonstrated a significant $8-\mathrm{OHdG}$ elevation in heart and lung tissues as a result of the exposure to $\mathrm{Fe}_{2} \mathrm{O}_{3} \mathrm{NPs}$ and AgNPs, with a even more prominent increase when rats were subjected to the combined NPs. Furthermore, NOx and TBARS were used as markers of lipid peroxidation with increased levels detected following exposure to NPs. The accumulation of these forms of oxidative damage results in DNA mutations and genotoxicity that may cause cell death (apoptotic or necrotic) or malignant transformation.

The ability of NPs to induce cell death is well documented (17). A previous study reported that AgNPs induces genotoxicity and cytotoxicity in cancer and normal cell lines, alters cell morphology, reduces cell viability, and causes oxidative stress in lung fibroblast and glioblastoma cells (18). AgNP-induced cytotoxicity may be partially caused by the direct action of $\mathrm{Ag}^{+}$ions being released from $\mathrm{AgNPs}$ (19) and the subsequent enhanced generation of intracellular ROS and reactive nitrogen species (RNS), which are responsible for inducing oxidative and nitrosative damage. In turn, this results in lipid peroxidation of biological membranes, and elicits oxidative DNA and structural protein damage $(20,21)$.

Previous nanotoxicity studies conducted with $\mathrm{Fe}_{2} \mathrm{O}_{3} \mathrm{NPs}$ have conclusively determined that the production of ROS is a major causal factor of cell death (22). Rate of uptake of $\mathrm{Fe}_{2} \mathrm{O}_{3} \mathrm{NPs}$ is mediated by the mononuclear phagocytic system via endocytosis and then degraded in the lysosomes. This releases the free iron from $\mathrm{Fe}_{2} \mathrm{O}_{3} \mathrm{NPs}$, which affects the iron homeostasis (23). Free iron is then stored in the form of proteins, such as ferritin and haemosiderin, for further use in the body. However, when the iron storage capacity of these proteins is exceeded, iron overload occurs which triggers the production of ROS via the Fenton reaction. In accordance with the present results, many studies have documented the toxic effects of $\mathrm{Fe}_{2} \mathrm{O}_{3} \mathrm{NPs}$ resulting in cellular and DNA damage (9,22-25). $\mathrm{Fe}_{2} \mathrm{O}_{3} \mathrm{NPs}$ causes cell death, mitochondrial damage, and DNA damage in A549 cells (24). The genotoxic effects of $\mathrm{Fe}_{2} \mathrm{O}_{3} \mathrm{NPs}$ are mainly caused by the direct interaction with leached iron ions or various indirect factors, such as excessive ROS. The direct and indirect contact of $\mathrm{Fe}_{2} \mathrm{O}_{3} \mathrm{NPs}$ with DNA can affect the structure of DNA causing strand breaks, cross-linking, and oxidation of nucleotides as well as affecting DNA transcription and replication. In addition, $\mathrm{Fe}_{2} \mathrm{O}_{3} \mathrm{NPs}$ upregulate genes that are associated with endothelial layer integrity and lysosomal function (25).

A further effect of exposure to NPs is an elevated inflammatory response at the cellular level, as demonstrated by various studies $(1,2,5,6,9,26)$. A large variety of soluble factors including ILs, TNF- $\alpha$, ROS and RNS are inflammatory response factors that mediate inflammation. These inflammatory factors promote DNA damage such as chromosomal fragmentation, DNA point mutations, inhibition of DNA repair and formation of methylation patterns, that may lead to altered gene expression profiles and the formation of DNA adducts (26).

The present study confirmed the proinflammatory effects of $\mathrm{Fe}_{2} \mathrm{O}_{3} \mathrm{NPs}$ and AgNPs particularly when combined. For example, significantly higher levels of TNF- $\alpha$ and IL-6 in cardiac and lung tissues were detected. In accordance with these results, Zhu et al (6) reported that intravascular $\mathrm{Fe}_{2} \mathrm{O}_{3} \mathrm{NPs}$ induces endothelial system inflammation and dysfunction via either direct interaction with the endothelial monolayer or indirectly by releasing free iron, thus impacting the endothelial cells and provoking oxidative stress responses. $\mathrm{Fe}_{2} \mathrm{O}_{3} \mathrm{NPs}$ have evident intratracheal toxic effects as they cause specific pathomorphological damage in rat lungs and irreversible injury to the membranes of alveolar cells (9).

NPs are known to upregulate the transcription of various proinflammatory genes, including TNF- $\alpha$, IL-1, IL-6, and IL-8, by activating NF- $\kappa$ B signaling. These sequential molecular and cellular events are known to cause oxidative stress, followed by severe cellular genotoxicity and then programmed cell death through activation of the JNK, p53 and NF- $\mathrm{KB}$ pathways. $\mathrm{Fe}_{2} \mathrm{O}_{3} \mathrm{NP}$ - and $\mathrm{AgNP}$-induced inflammatory responses in murine tissues, such as the heart and lung have been well documented $(27,28)$. It has also been documented that particle deposition in the lung causes recruitment of inflammatory cells that generate ROS, clastogenic factors, and cytokines either harming or stimulating resident lung cells (29).

Indices of oxidative damage on lipids and DNA molecules indicate that heart and lung tissues suffer oxidative stress damage not only as a result of increased ROS generation but also due to the impairment of the antioxidant mechanism caused by NP exposure. The present study demonstrated that $\mathrm{Fe}_{2} \mathrm{O}_{3} \mathrm{NPs}$ and $\mathrm{AgNPs}$ significantly hampered the main antioxidant processes in heart and lung tissues including levels of antioxidant enzymes SOD, GST, GPx, and CAT, TAC, and the GSH system. Therefore, a growing body of evidence, including the present findings, confirm the pro-oxidant effects of $\mathrm{Fe}_{2} \mathrm{O}_{3} \mathrm{NPs}$ and AgNPs $(30,31)$.

Besides their general pro-oxidant and proinflammatory effects, $\mathrm{Fe}_{2} \mathrm{O}_{3} \mathrm{NPs}$ and $\mathrm{AgNPs}$ also induced specific metabolic alterations that may have important roles as atherogenic factors. PON1 is a hydrolytic enzyme with a wide range of substrates that is able to protect against lipid oxidation. The atheroprotective effects of PON1 are achieved through inhibition of LDL oxidation, reducing the risk of cardiovascular disease (32). The present results demonstrated that exposure to $\mathrm{Fe}_{2} \mathrm{O}_{3} \mathrm{NPs}$ and AgNPs alone or in combination caused depletion of PON1 in the plasma and heart tissues. The PON1 decline, together with the documented dyslipidemia including HDL-c decrease and elevation of triglycerides, cholesterol, LDL-c and total lipids, are strong atherogenic factors that predisposed the rats towards developing cardiovascular diseases. This risk is evidenced by the significant elevation of CK-MB plasma and cardiac activity as well as the histological abnormalities of cardiac tissues including myocardial congestion and degeneration. The increased activity of CK-MB in cardiac tissues due to $\mathrm{Fe}_{2} \mathrm{O}_{3} \mathrm{NPs}$ and AgNPs exposure may lead to disruption of the specific role of $\mathrm{CK}$ in the excitation-contraction mechanism. In addition, the high plasma activity of CK-MB is an indication of myocardial injury. In agreement with the present results, Nemmar et al (33) reported that $\mathrm{Fe}_{2} \mathrm{O}_{3} \mathrm{NPs}$ increases CK-MB levels in the heart and plasma tissues. Similarly, Shen et al (34) reported that $\mathrm{Fe}_{2} \mathrm{O}_{3} \mathrm{NPs}$ attack the myocardium muscles inducing myocardial iron overload, resulting in myocardial injury and deterioration of cardiac function via oxidative stress-mediated iron toxicity. Histology findings revealed myocyte apoptosis, inflammation, and fibrosis. 
Furthermore, Rathore et al (35) concluded that the heart muscle fibers treated with AgNPs demonstrated mild edema and separation of myofibrils. In addition, Adeyemi and Faniyan (36) documented that AgNPs cause inflammation, loss of cross striation with myocardial degeneration and cellular alteration in the cardiac tissue of male Wistar rats. Warheit et al (37) reported that in rat lungs exposed to $\mathrm{Fe}_{2} \mathrm{O}_{3} \mathrm{NPs}$, the interstitium widened and was infiltrated with lymphocytes, macrophages, and plasma cells and fibrosis developed.

In summary, the present study determined the adverse effects of long-term exposure to $\mathrm{Fe}_{2} \mathrm{O}_{3} \mathrm{NPs}$ and AgNPs on the heart and lungs. Cardiotoxicity and lung toxicity were induced via different pathways including oxidative DNA modification, induction of inflammation, free radical generation, and inhibition of antioxidant mechanisms. In addition, NPs caused alterations in heart and lung histology and lipid profiles. Furthermore, the results evidently demonstrated that simultaneous co-exposure to $\mathrm{Fe}_{2} \mathrm{O}_{3} \mathrm{NPs}$ and AgNPs resulted in greater ramifications to the heart and lungs compared to the effect of individual NPs. The possible adverse effects on other rat organs coexposed to $\mathrm{Fe}_{2} \mathrm{O}_{3} \mathrm{NPs}$ and AgNPs will be further investigated with focus on the male reproductive system, liver and brain. In conclusion, the present findings raise concerns about the synergistic effects of different NPs in inducing chronic toxicity on the heart and lungs, and the impact this may have on the subsequent predisposition to cardiovascular and pulmonary diseases.

\section{Acknowledgements}

Not applicable.

\section{Funding}

No funding received.

\section{Availability of data and materials}

The datasets used and/or analyzed during the current study are available from the corresponding author on reasonable request.

\section{Authors' contributions}

MIY suggested the research topic, participated in the experimental design and contributed to the writing of the paper. AAA performed most experiments, carried out the statistical analysis of data and helped in the writing of the paper. MANK designed the experiments, performed the molecular experiments, and contributed to the writing and revising of the paper. All authors have read and approved the final paper.

\section{Ethics approval and consent to participate}

All experimental procedures, animal handling, sampling, and scarification were conducted in accordance with the Guide for the Care and Use of Laboratory Animals, 8th edition (National Research Council 2011) and were approved by the Research Ethical Committee of the Medical Research Institute, Alexandria University. All efforts were made to minimise the rats' suffering during the experimental period.

\section{Patient consent for publication}

Not applicable.

\section{Competing interests}

The authors declare that they have no competing interests.

\section{References}

1. Oberdörster G, Stone V and Donaldson K: Toxicology of nanoparticles: A historical perspective. Nanotoxicology 1: 2-25, 2007.

2. Karlsson HL, Gustafsson J, Cronholm P and Möller L: Size-dependent toxicity of metal oxide particles-a comparison between nano-and micrometer size. Toxicol Lett 188: 112-118, 2009.

3. Senapati S, Ahmad A, Khan MI, Sastry M and Kumar R: Extracellular biosynthesis of bimetallic AuAg alloy nanoparticles. Small 1: 517-520, 2005.

4. Khan I, Saeed K and Khan I: Nanoparticles: Properties, applications and toxicities. Arab J Chem: MAy 18, 2017 (Epub ahead of print). doi: 10.1016/j.arabjc.2017.05.011.

5. Akter M, Sikder T, Rahmana M, Ullah A, Hossain KFB, Banik S, Hosokawa T, Saito T and Kurasaki M: A systematic review on silver nanoparticles-induced cytotoxicity: Physicochemical properties and perspectives. J Adv Res 9: 1-16, 2018.

6. Zhu MT, Wang B, Wang Y, Yuan L, Wang HJ, Wang M, Ouyang H, Chai ZF, Feng WY and Zhao YL: Endothelial dysfunction and inflammation induced by iron oxide nanoparticle exposure: Risk factors for early atherosclerosis. Toxicol Lett 203: 162-171, 2011.

7. Liu J and Hurt RH: Ion release kinetics and particle persistence in aqueous nano-silver colloids. Environ Sci Technol 44: 2169-2175, 2010.

8. Bar-Ilan O, Albrecht RM, Fako VE and Furgeson DY: Toxicity assessments of multisized gold and silver nanoparticles in zebrafish embryos. Small 5: 1897-1910, 2009.

9. Szalay B, Tátrai E, Nyírő G, Vezér T and Dura G: Potential toxic effects of iron oxide nanoparticles in vivo and in vitro experiments. J Appl Toxicol 32: 446-453, 2012.

10. Sharma VK, Yngard RA and Lin Y: Silver nanoparticles: Green synthesis and their antimicrobial activities. Adv Colloid Interface Sci 145: 83-96, 2009.

11. The University of Iowa. Office of animal resources: Institutional animal care and use committee. IACUC Guidelines: Anesthesia. https://animal.research.uiowa.edu/iacuc-guidelines-anesthesia. Accessed December 26, 2018.

12. Draper HH and Hadley M: Malondialdehyde determination as index of lipid peroxidation. Methods Enzymol 186: 421-431, 1990.

13. Guevara I, Iwanejko J, Dembińska-Kieć A, Pankiewicz J, Wanat A, Anna P, Gołabek I, Bartuś S, Malczewska-Malec M and Szczudlik A: Determination of nitrite/nitrate in human biological material by the simple Griess reaction. Clin Chim Acta 274: 177-188, 1998.

14. Griffith OW: Determination of glutathione and glutathione disulfide using glutathione reductase and 2-vinylpyridine. Anal Biochem 106: 207-212, 1980.

15. Mueller RF, Hornung S, Furlong CE, Anderson J, Giblett ER and Motulsky AG: Plasma paraoxonase polymorphism: A new enzyme assay, population, family, biochemical, and linkage studies. Am J Hum Genet 35: 393-408, 1983.

16. Drury RA and Wallington EA: Carleton's Histological Techniques. 6th edition. Oxford University Press. New York, NY, Toronto, 1980.

17. Fumagalli M, Rossiello F, Clerici M, Barozzi S, Cittaro D, Kaplunov JM, Bucci G, Dobreva M, Matti V, Beausejour CM, et al: Telomeric DNA damage is irreparable and causes persistent DNA-damage response activation. Nat Cell Biol 14: 355-365, 2012.

18. Asharani PV, Hande MP and Valiyaveettil S: Anti-proliferative activity of silver nanoparticles. BMC Cell Biol 10: 65, 2009.

19. Singh RP and Ramarao P: Cellular uptake, intracellular trafficking and cytotoxicity of silver nanoparticles. Toxicol Lett 213: 249-259, 2012

20. Foldbjerg R, Olesen P, Hougaard M, Dang DA, Hoffmann HJ and Autrup H: PVP-coated silver nanoparticles and silver ions induce reactive oxygen species, apoptosis and necrosis in THP-1 monocytes. Toxicol Lett 190: 156-162, 2009. 
21. Kim SH, Ko JW, Koh SK, Lee IC, Son JM, Moon C, Kim SH Shin DH and Kim JC: Silver nanoparticles induce apoptotic cell death in cultured cerebral cortical neurons. Mol Cell Toxicol 10 173-179, 2014

22. Patil US, Adireddy S, Jaiswal A, Mandava S, Lee BR and Chrisey DB: In vitro/in vivo toxicity evaluation and quantification of iron oxide nanoparticles. Int J Mol Sci 16: 24417-24450, 2015.

23. Voinov MA, Sosa Pagán JO, Morrison E, Smirnova TI and Smirnov AI: Surface-mediated production of hydroxyl radicals as a mechanism of iron oxide nanoparticle biotoxicity. J Am Chem Soc 133: 35-41, 2010.

24. Lee JH, Ju JE, Kim BI, Pak PJ, Choi EK, Lee HS and Chung N: Rod-shaped iron oxide nanoparticles are more toxic than sphere-shaped nanoparticles to murine macrophage cells. Environ Toxicol Chem 33: 2759-2766, 2014.

25. Alarifi S, Ali D and Alkahtani S: Nanoalumina induces apoptosis by impairing antioxidant enzyme systems in human hepatocarcinoma cells. Int J Nanomedicine 10: 3751-3760, 2015

26. Park EJ and Park K: Oxidative stress and pro-inflammatory responses induced by silica nanoparticles in vivo and in vitro. Toxicol Lett 184: 18-25, 2009.

27. Pujalté I, Passagne I, Brouillaud B, Tréguer M, Durand E, Ohayon-Courtès C and L'Azou B: Cytotoxicity and oxidative stress induced by different metallic nanoparticles on human kidney cells. Part Fibre Toxicol 8: 10, 2011.

28. Mukaetova-Ladinska EB, Garcia-Siera F, Hurt J, Gertz HJ, Xuereb JH, Hills R, Brayne C, Huppert FA, Paykel ES McGee M, et al: Staging of cytoskeletal and beta-amyloid changes in human isocortex reveals biphasic synaptic protein response during progression of Alzheimer's disease. Am J Pathol 157: 623-636, 2000.

29. Nel A, Xia T, Mädler L and Li N: Toxic potential of materials at the nanolevel. Science 311: 622-627, 2006.
30. Wang A, Pu K, Dong B, Liu Y, Zhang L, Zhang Z, Duan W and Zhu Y: Role of surface charge and oxidative stress in cytotoxicity and genotoxicity of graphene oxide towards human lung fibroblast cells. J Appl Toxicol 33: 1156-1164, 2013.

31. McShan D, Ray PC1 and Yu H: Molecular toxicity mechanism of nanosilver. J Food Drug Anal 22: 116-127, 2014.

32. Litvinov D, Mahini $\mathrm{H}$ and Garelnabi M: Antioxidant and anti-inflammatory role of paraoxonase 1: Implication in arteriosclerosis diseases. N Am J Med Sci 4: 523-532, 2012.

33. Nemmar A, Beegam S, Yuvaraju P, Yasin J, Tariq S, Attoub S and Ali BH: Ultrasmall superparamagnetic iron oxide nanoparticles acutely promote thrombosis and cardiac oxidative stress and DNA damage in mice. Part Fibre Toxicol 13: 22, 2016.

34. Shen Y, Huang Z, Liu X, Qian J, Xu J, Yang X, Sun A and Ge J: Iron-induced myocardial injury: An alarming side effect of superparamagnetic iron oxide nanoparticles. J Cell Mol Med 19: 2032-2035, 2015.

35. Rathore M, Mohanty IR, Maheswari U, Dayal N, Suman R and Joshi DS: Comparative in vivo assessment of the subacute toxicity of gold and silver nanoparticles. J Nanopart Res 16: 2338, 2014.

36. Adeyemi OS and Faniyan TO: Antioxidant status of rats administered silver nanoparticles orally. J Taibah Univ Med Sci 9: 182-186, 2014.

37. Warheit DB, Sayes CM, Reed KL and Swain KA: Health effects related to nanoparticle exposures: Environmental, health and safety considerations for assessing hazards and risks. Pharmacol Ther 120: 35-42, 2008.

This work is licensed under a Creative Commons Attribution-NonCommercial-NoDerivatives 4.0 International (CC BY-NC-ND 4.0) License. 